\title{
Pulmonary function test values due to a diaphragmatic hernia
}

\author{
Jesper Rømhild Davidsen, Leo Nygaard, Christian B Laursen, \\ Daniel Pilsgaard Henriksen
}

Department of Respiratory Medicine, Odense University Hospital, Odense, Denmark

\section{Correspondence to} Dr Jesper Rømhild Davidsen, jesper.roemhild.davidsen@rsyd. $\mathrm{dk}$

Accepted 30 July 2016

\section{DESCRIPTION}

A 67-year-old never-smoking man with a wellknown congenital diaphragmatic hernia, verified on a 3-year-old chest X-ray (figure 1), consulted his general practitioner due to the detection of intermittent blood stool for 2 months, but emphasised also an increasing dyspnoea during this period corresponding to a medical research council dyspnoea scale 3. He was referred for colonoscopy, but prior to this a CT scan of the thorax and abdomen was performed showing progression of the left-sided diaphragmatic hernia with now almost the entire small intestine localised in the left hemithorax (figure 2). Despite the radiological findings, the patient had no symptoms from the gastrointestinal tract, and colonoscopy only revealed a non-malignant

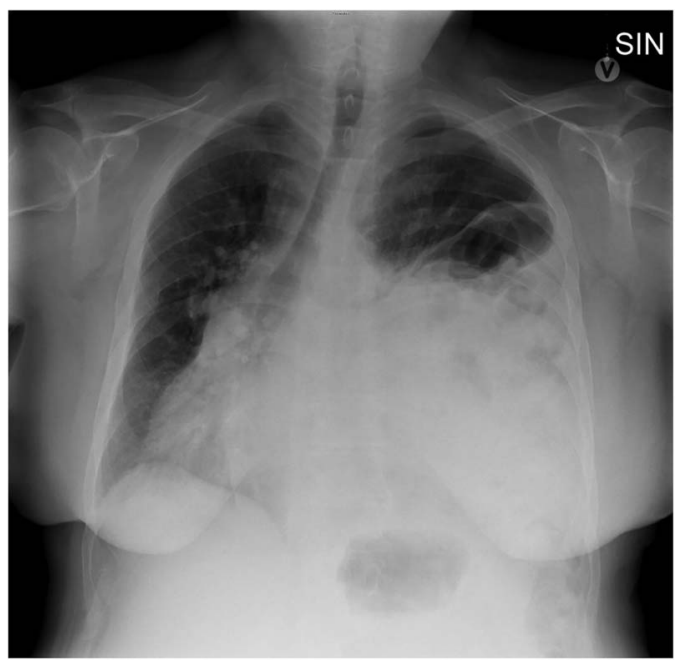

Figure 1 Chest $\mathrm{X}$-ray in posterior to anterior projection performed 3 years earlier.

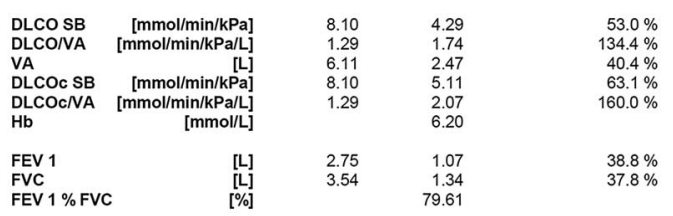

Figure 3 Spirometry data including forced expiratory ventilation in $1 \mathrm{~s}\left(\mathrm{FEV}_{1}\right)$, forced vital capacity (FVC), single-breath (SB) haemoglobin corrected (c) diffusion lung capacity for carbon monoxide (DLCO) showing severe restriction in ventilation capacity and, when adjusting for alveolar volume (VA), a normal diffusion coefficient (DLCO/VA=KCO). Values in per cent correspond to per cent of predicted values.

colon polyp as the most reliable cause of blood stool. The patient was subsequently referred for pulmonary evaluation where a pulmonary function test (PFT) including single-breath diffusion lung capacity for carbon monoxide showed a reduced diffusion capacity of $63 \%$ of predicted value (pred.), a hyper normal diffusion coefficient (KCO) corresponding to $160 \%$ pred., and a severe restriction in ventilation capacity with a forced expiratory volume in $1 \mathrm{~s}\left(\mathrm{FEV}_{1}\right)$, a forced vital capacity (FVC) and a $\mathrm{FEV}_{1} / \mathrm{FVC}$ corresponding to $39 \%$ pred., $38 \%$ pred. and $80 \%$ pred., respectively (figure 3). ${ }^{1}$ No static lung function measurements were performed.

Diaphragmatic hernia is a well-known cause of restrictive ventilation pattern on PFT which is also present in interstitial lung diseases (ILDs) and secondary to a pneumonectomy. However, a reduced $\mathrm{KCO}$ is expected in ILD unlike a normal and a sometimes even slighter increase in $\mathrm{KCO}$ in cases presenting with diaphragmatic hernia or pneumonectomy, respectively. ${ }^{2}{ }^{3}$ In such cases the specific
To cite: Davidsen JR, Nygaard L, Laursen $C B$ et al. BMJ Case Rep Published online: [please include Day Month Year] doi:10.1136/bcr-2016216542

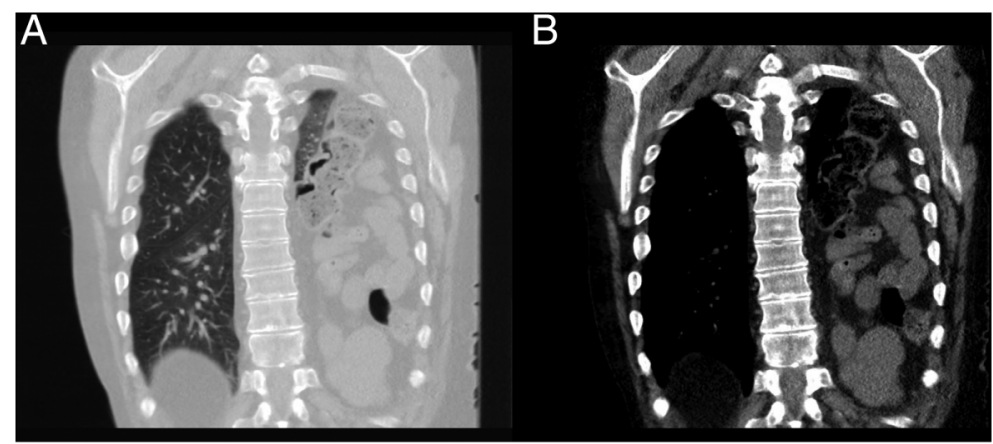

Figure 2 CT image of the thorax showing an enormously left-sided diaphragmatic hernia with almost the entire small intestine localised in the left hemithorax ((A) lung window; (B) chest-abdominal window). 
combination of ventilation and diffusion parameters from a PFT may indicate a potential underlying aetiology of the respiratory condition which may be uncovered and clarified by thoracic imaging.

\section{Learning points}

- Diaphragmatic hernias can lead to an intrathoracic space-occupying lesion causing a restrictive lung disease pattern with an oftentimes normal diffusion coefficient.

- An unexplained restrictive ventilation pattern should be followed up by thoracic imaging in order to uncover the potential underlying aetiology.
Acknowledgements CT scan was performed with courtesy of the Department of Radiology, Odense University Hospital, Denmark.

Contributors JRD, LN, CBL and DPH contributed to the conception of the article, drafted the submitted article and approved the final version to be published.

Competing interests None declared.

Patient consent Obtained.

Provenance and peer review Not commissioned; externally peer reviewed.

\section{REFERENCES}

1 Godfrey MS, Jankowich MD. The vital capacity is vital: epidemiology and clinical significance of the restrictive spirometry pattern. Chest 2016;149:238-51.

2 Ngaage DL, Young RA, Cowen ME. An unusual combination of diaphragmatic hernias in a patient presenting with the clinical features of restrictive pulmonary disease: report of a case. Surg Today 2001;31:1079-81.

3 Berend N. Respiratory disease and respiratory physiology: putting lung function into perspective interstitial lung disease. Respirology 2014;19:952-9.

Copyright 2016 BMJ Publishing Group. All rights reserved. For permission to reuse any of this content visit http://group.bmj.com/group/rights-licensing/permissions.

BMJ Case Report Fellows may re-use this article for personal use and teaching without any further permission.

Become a Fellow of BMJ Case Reports today and you can:

- Submit as many cases as you like

- Enjoy fast sympathetic peer review and rapid publication of accepted articles

- Access all the published articles

- Re-use any of the published material for personal use and teaching without further permission

For information on Institutional Fellowships contact consortiasales@bmjgroup.com

Visit casereports.bmj.com for more articles like this and to become a Fellow 